\title{
Reaction of benzal bromides in water/dioxane system for easy access to benzaldehydes and 2 -formylbenzonitriles (2-cyanobenzaldehydes)
}

\author{
Antonia Di Mola, ${ }^{b}$ Tonino Caruso,${ }^{a}$ Paolo De Caprariis, ${ }^{b}$ and Antonio Massa ${ }^{* a}$ \\ ${ }^{a}$ Dipartimento di Chimica e Biologia, Università di Salerno, Via Giovanni Paolo II, 132, \\ 84084-Fisciano (SA), Italy \\ ${ }^{b}$ Dipartimento di Farmacia, Università di Salerno, Via Giovanni Paolo II, 132, \\ 84084-Fisciano (SA), Italy \\ E-mail: amassa@unisa.it
}

DOI: $\underline{\text { http://dx.doi.org/10.3998/ark.5550190.p009.463 }}$

\begin{abstract}
A convenient method of synthesis of substituted benzaldehydes and 2-formylbenzonitriles has been described by reaction of the easily available benzal dibromides in a dioxane/water system.
\end{abstract}

Keywords: Benzonitriles, benzaldehydes, benzal bromides

\section{Introduction}

2-Formylbenzonitriles 1 are useful starting materials for the preparation of phthalides ${ }^{1}$ or nitrogencontaining heterocycles such as isoindolinones ${ }^{2-12}$ and isoindoles ${ }^{13-14}$ (compounds 2-5, Figure 1), which have been shown to possess a wide range of biological activities.

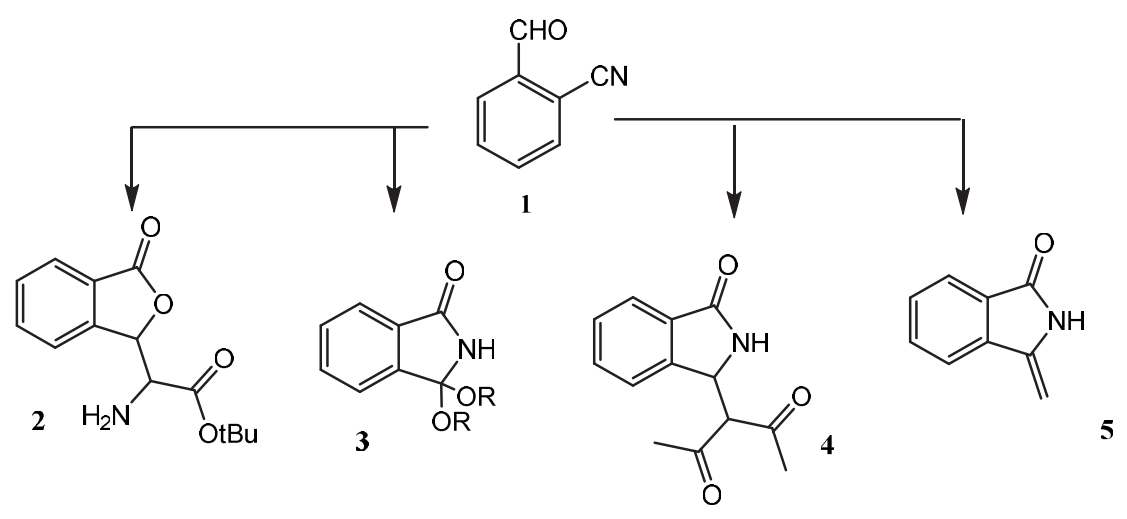

Figure 1. Examples of heterocycles prepared from 2-formylbenzonitriles. 
However, 2-formylbenzonitriles are not cheap compounds and to our knowledge relatively few methodologies which describe their synthesis have been reported (Figure 2) ${ }^{2,5-7,15-17}$ In addition, many of the existing synthetic methods suffer from certain limitations with respect to yield, reaction conditions and toxicity. In particular, the formylations of $\mathbf{6}$, performed under strongly basic conditions, usually lead to $\mathbf{1}$ in rather low yields. ${ }^{2,18}$ Similar disappointing results are obtained in the reaction of $\mathbf{8}$ with the toxic $\mathrm{CuCN}^{2,19}$ On the other hand, the transformation of gem-dihalo compounds (benzal halides) into benzaldehydes is quite a common method. ${ }^{20-30}$ In this case solvolytic displacement of halogen with successive replacement by hydroxyl followed by formal loss of $\mathrm{HBr}$ to generate the corresponding aldehyde, is favored by resonance stabilization offered by the aromatic ring. ${ }^{29}$
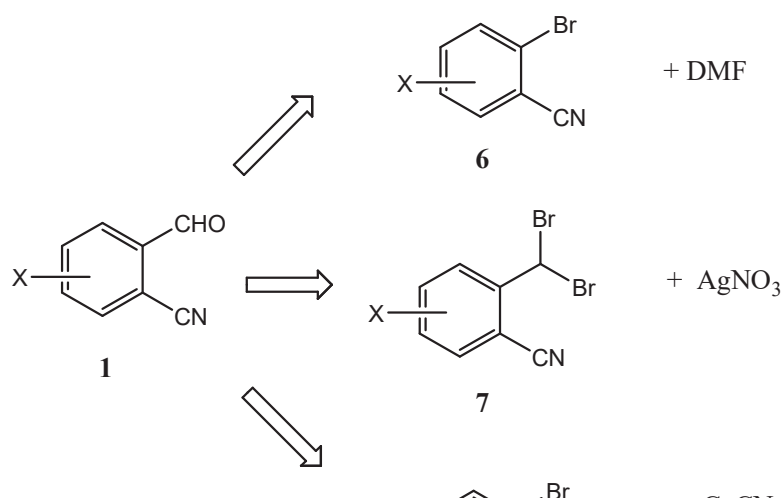

7

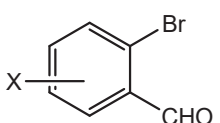

$+\mathrm{CuCN}$

8

Figure 2. Common approaches to 2-formylbenzonitriles.

Hydrolysis of the benzal halides to the corresponding aldehydes is often conducted in the presence of strong acids (e.g., $95 \% \mathrm{H}_{2} \mathrm{SO}_{4}$ ) or strong bases (aq. $\mathrm{NaOH}$ ) at high temperatures, ${ }^{25-26}$ conditions too harsh for the synthesis of 2-formylbenzonitriles, Therefore, the transformation of benzal halides 7 into 2-formylbenzonitriles have been reported under milder conditions only in the presence of the rather expensive $\mathrm{AgNO}_{3}$, used in large excess ( $>3$ eq. $),{ }^{5-7}$ with severe limitations concerning the scale of the synthetic procedure, the necessity of additional tedious purification operations and eventual metal contamination. In our ongoing project on large-scale reaction of 2formylbenzonitriles, we came across these problems and we realized that not much attention has been devoted to the development of simple and effective methods for the synthesis of these valuable aldehydes. Thus, in this article, we have reconsidered the reactivity of benzal bromides 7, developing a convenient approach to 2-formylbenzonitriles, and then we have extended the method to the synthesis of other model benzaldehydes. 


\section{Results and Discussion}

During our investigations into the large-scale synthesis of 2-formylbenzonitrile 1a by hydrolysis of the respective benzal bromide, instead of using the classical procedure based on large amounts of $\mathrm{AgNO}_{3}$ in refluxing $\mathrm{CH}_{3} \mathrm{CN} / \mathrm{H}_{2} \mathrm{O},{ }^{5-7}$ we investigated the simple water/dioxane mixture, a system with high boiling temperature in which the substrate $7 \mathbf{a}$ is well soluble. Under the conditions of Scheme 1, we were pleased to observe the formation of the desired 2-formylbenzonitrile $(X=H)$ in very high yield in a reasonable reaction time (Table 1, entry 1). The reaction was also performed at $10 \mathrm{mmol}$ scale with similar efficiency, particularly useful for preparative purposes, since 1a can be recovered from the workup in high purity after a short chromatographic purification (Table 1, entry 2).

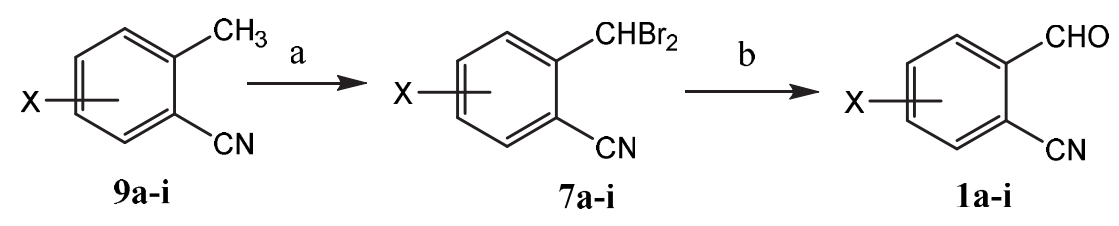

$\mathrm{X}=\mathrm{H}, 5-\mathrm{NO}_{2}, 5-\mathrm{Cl}, 5-\mathrm{F}, 5-\mathrm{Br}, 5-\mathrm{I}, 5-\mathrm{OCH}_{3}, 5-\left[\left(3,4-\left(\mathrm{CH}_{3} \mathrm{O}\right)_{2} \mathrm{C}_{6} \mathrm{H}_{3}\right], 4-\mathrm{NO}_{2}\right.$

Reagents and conditions: a) $\mathrm{N}$-bromosuccinimide, dibenzoyl peroxide, $\mathrm{CCl}_{4}$, reflux;

b) dioxane/water (1/1), reflux, $24 \mathrm{~h}$.

\section{Scheme 1}

In addition, in a control experiment, we tried the hydrolysis of $6 \mathbf{a}$ only in refluxing $\mathrm{CH}_{3} \mathrm{CN} / \mathrm{H}_{2} \mathrm{O}$. However, we observed low conversion (about 50\%), low yield $(30 \%)$ and decomposition products (Entry 3), pointing out both the necessity to use the silver salts in large excess, as required by the literature procedure, ${ }^{5}$ and at the same time highlighting the efficacy of our methodology. Then, in order to enlarge the scope of the method, we focused on the hydrolysis of other benzal bromides, easily obtained in high yields by radical dibromination of different 2methylbenzonitriles 9.5-7 The 2-methylbenzonitriles 9a, 9c, 9d and $9 \mathbf{i}\left(\mathrm{X}=\mathrm{H}, 5-\mathrm{Cl}, 5-\mathrm{F}\right.$ and 4- $\left.\mathrm{NO}_{2}\right)$ are commercially available. Other substrates $\mathbf{9 b}, \mathbf{9 e - h}$ bearing different groups, like 5-nitro, methoxy, halogens (Br and I) and 3,4-dimethoxyphenyl were conveniently obtained according to the synthetic route shown in Scheme 2, giving access to a range of starting materials which were submitted to the radical dibromination. 


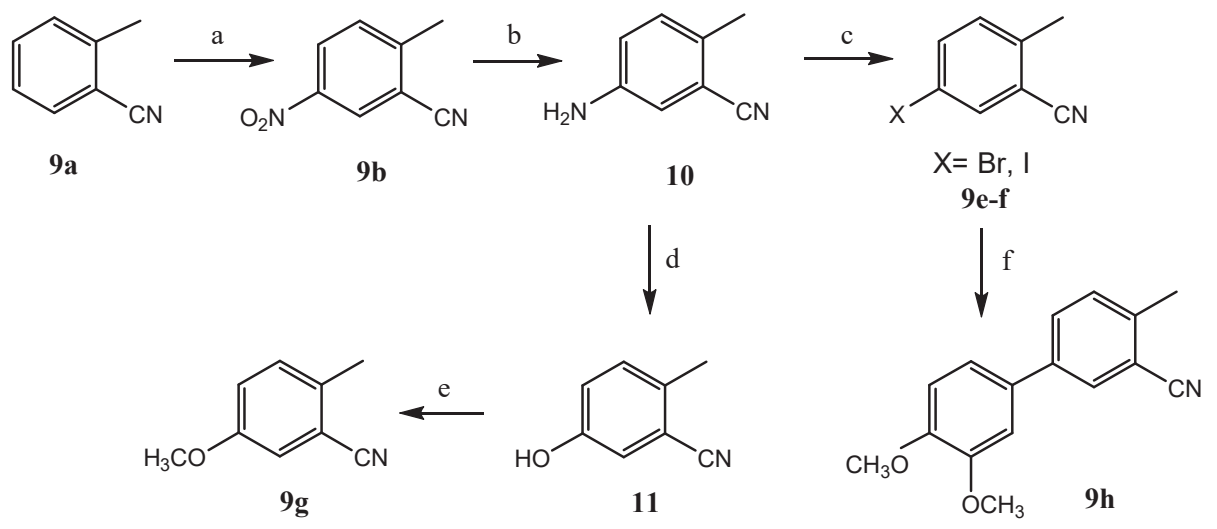

Reagents and conditions. a) $\mathrm{HNO}_{3}$ fuming, $\mathrm{H}_{2} \mathrm{SO}_{4}, 0{ }^{\circ} \mathrm{C}, 2 \mathrm{~h}, 92 \%$; b) $\mathrm{Zn} / \mathrm{HCl}$ conc. $\mathrm{MeOH}$, overnight, $95 \%$; c) $\mathrm{NaNO}_{2}, 0{ }^{\circ} \mathrm{C}, \mathrm{HX}, \mathrm{CuX}$ or KX, $72 \%$ (9d), $43 \%$ (9e); d) $\mathrm{H}_{2} \mathrm{SO}_{4}, \mathrm{NaNO}_{2},{ }^{\circ} \mathrm{C}$; then water, reflux, $55 \%$., e) $\mathrm{CH}_{3} \mathrm{I}$, $\mathrm{K}_{2} \mathrm{CO}_{3}, \mathrm{DMF}, 80^{\circ} \mathrm{C}, 91 \%$, f) X=I, 3,4 dimethoxyphenyl boronic acid, $\mathrm{Pd}\left(\mathrm{PPh}_{3}\right)_{4}, \mathrm{EtOH}, \mathrm{K}_{2} \mathrm{CO}_{3}$, reflux, $87 \%$.

Scheme 2. Preparation of $o$-methylbenzonitriles 9 e-h.

With the collection of benzal bromides $7 \mathbf{b}$-i now available, we performed the respective hydrolysis under the developed conditions, which afforded the corresponding formyl benzonitriles in moderate to good yields (Table 1).

Table 1. 2-Formyl benzonitriles synthesized in water/dioxane system (see Scheme 1)

\begin{tabular}{|c|c|c|c|c|c|}
\hline Entry $^{a}$ & Substrate & $\mathrm{X}$ & Product & Yield $^{b}$ & Time \\
\hline 1 & $7 a$ & $\mathrm{H}$ & $1 \mathrm{a}$ & $94 \%$ & $16 \mathrm{~h}$ \\
\hline $2^{c}$ & $7 a$ & $\mathrm{H}$ & $1 \mathrm{a}$ & $89 \%$ & $24 \mathrm{~h}$ \\
\hline $3^{d}$ & $7 a$ & $\mathrm{H}$ & $1 \mathrm{a}$ & $30 \%$ & $24 \mathrm{~h}$ \\
\hline 4 & $7 b$ & $5-\mathrm{NO}_{2}$ & $1 b$ & $38 \%(51 \%)^{e}$ & $48 \mathrm{~h}$ \\
\hline 5 & $7 \mathrm{c}$ & $5-\mathrm{Cl}$ & $1 \mathrm{c}$ & $75 \%$ & $24 \mathrm{~h}$ \\
\hline 6 & 7d & $5-\mathrm{F}$ & 1d & $76 \%$ & $24 \mathrm{~h}$ \\
\hline 7 & $7 e$ & $5-\mathrm{Br}$ & $1 \mathrm{e}$ & $73 \%$ & $24 \mathrm{~h}$ \\
\hline 8 & $7 f$ & $5-\mathrm{I}$ & 1f & $73 \%$ & $24 \mathrm{~h}$ \\
\hline 9 & $7 \mathrm{~g}$ & $5-\mathrm{OCH}_{3}$ & $1 \mathrm{~g}$ & $76 \%$ & $16 \mathrm{~h}$ \\
\hline 10 & $7 \mathrm{~h}$ & $\begin{array}{c}5-(3,4-d i- \\
\left.\mathrm{CH}_{3} \mathrm{O}\right) \mathrm{C}_{6} \mathrm{H}_{3}\end{array}$ & $1 \mathrm{~h}$ & $71 \%$ & $28 \mathrm{~h}$ \\
\hline 11 & $7 \mathbf{i}$ & $4-\mathrm{NO}_{2}$ & $1 \mathrm{i}$ & $15 \%(67 \%)^{e}$ & $48 \mathrm{~h}$ \\
\hline
\end{tabular}

${ }^{a}$ Reaction carried out on $0.6 \mathrm{mmol} \mathrm{scale} ;{ }^{b}$ Isolated yield; ${ }^{c}$ reaction carried out on $10 \mathrm{mmol}$ scale; ${ }^{d}$ reaction performed in refluxing mixture of $\mathrm{CH}_{3} \mathrm{CN} / \mathrm{H}_{2} \mathrm{O}(5 \mathrm{~mL}, 1 / 1) ;{ }^{e}$ in parentheses yield of the recovered starting materials 
The reaction rates were dependent upon the substituent. The obtained results are, however, comparable with those reported in literature for the hydrolysis performed in the presence of $\mathrm{AgNO}_{3}{ }^{5-7}$ In addition, the methodology herein described allows the access to several new 2formylbenzonitriles (products $\mathbf{1 b}, \mathbf{c}, \mathbf{f - i}$ ). Only the benzal bromides bearing the $5-\mathrm{NO}_{2}$ and $4-\mathrm{NO}_{2}$ substituents (7b and 7i) were less reactive, giving the respective aldehydes in rather low yields (Entry 4 and 11). In these cases, we recovered a large amount of the starting materials (about 50\%) and we observed the formation of smaller amount of a byproduct corresponding to the 3hydroxyphthalide (about 10\%), ${ }^{31,32}$ as a consequence of the competitive cyclization on $\mathbf{1 b}$ at the cyano group and the hydrolysis of the obtained imidate. For comparison, a control experiment performed on $\mathbf{7} \mathbf{b}$ in the presence of $\mathrm{AgNO}_{3}$ gave only decomposition products, and $\mathbf{1 b}$ was not detected.

Next, we investigated the hydrolysis of some well-known model benzal bromides in order to further determine the scope and limitations of the approach, and for comparison with other methods reported in the literature for the same transformation. ${ }^{27,28}$ Under the described conditions, the hydrolysis was also effective in the synthesis of the benzaldehyde and of other monosubstituted benzaldehydes bearing different substituents (Table 2).

Table 2. Application of the method in the synthesis of model benzaldehydes

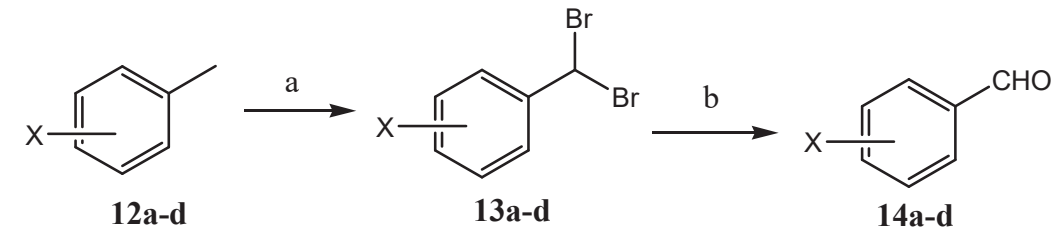

\begin{tabular}{cccccc}
\hline Entry & Substrate & $\mathrm{X}$ & Product & Yield $^{a}$ & Time \\
\hline 1 & $\mathbf{1 3 a}$ & $\mathrm{H}$ & $\mathbf{1 4 a}$ & $96 \%$ & $16 \mathrm{~h}$ \\
2 & $\mathbf{1 3 b}$ & $4-\mathrm{CN}$ & $\mathbf{1 4 b}$ & $95 \%$ & $24 \mathrm{~h}$ \\
3 & $\mathbf{1 3 c}$ & $4-\mathrm{OCH}_{3}$ & $\mathbf{1 4 c}$ & $96 \%$ & $16 \mathrm{~h}$ \\
4 & $\mathbf{1 3 d}$ & $4-\mathrm{NO}_{2}$ & $\mathbf{1 4 d}$ & $78 \%(22 \%)^{b}$ & $48 \mathrm{~h}$ \\
\hline
\end{tabular}

${ }^{a}$ Isolated yield, ${ }^{b}$ yield of the recovered starting materials.

All pure products were isolated in very high yields from the workup without any further chromatographic purification, the results being somewhat better than or comparable with those reported in the literature. ${ }^{27,28}$ Only the dibromide bearing the strongly electron-withdrawing nitro group was less reactive, and unreacted starting material was recovered (Entry 4). 


\section{Conclusions}

In this paper we report that the simple water/dioxane system easily transforms benzal bromides into their corresponding benzaldehydes in good to high yield under refluxing conditions. The method is particularly convenient in comparison with others reported in the literature, especially for the synthesis of 2-formylbenzonitriles and for large scale applications.

\section{Experimental Section}

General. All reactions were performed using commercially available compounds without further purification. Column chromatographic purification of products was carried out using silica gel 60 (70-230 mesh, Merck). The NMR spectra were recorded on Bruker DRX 400, 300, 250 spectrometers (400 MHz, $300 \mathrm{MHz}, 250 \mathrm{MHz},{ }^{1} \mathrm{H} ; 100 \mathrm{MHz}, 75 \mathrm{MHz}, 62.5 \mathrm{MHz}{ }^{13} \mathrm{C}$ ). Spectra were referenced to residual $\mathrm{CHCl}_{3}\left(7.26 \mathrm{ppm},{ }^{1} \mathrm{H}, 77.23 \mathrm{ppm},{ }^{13} \mathrm{C}\right)$. Coupling constants $J$ are reported in Hz. Yields are given for isolated products showing one spot on a TLC plate and no impurities detectable in the NMR spectrum. Mass spectral analyses were carried out using an electrospray spectrometer Waters 4 micro quadrupole or Agilent GC-MSD 5975C with triple axis detector. Elemental analyses were performed with FLASHEA 1112 series-Thermo Scientific for CHNS-O apparatus. Compounds $7 \mathbf{a}, \mathbf{7 d}, \mathbf{9 b}, \mathbf{9 e}, \mathbf{1 0}$ and 13a were prepared according to the literature. ${ }^{5,33}$ Compounds 1a, 1c-e, 7a-d, 9f-g, 13a-d and 14a-d were identified comparing their spectral data with the literature reported. ${ }^{5,7,34-40}$ Spectroscopic data are given only for compounds never previously described.

5-Iodo-2-methylbenzonitrile (9f). ${ }^{34}$ Water $(10 \mathrm{~mL})$ and concentrated $\mathrm{HCl}$ solution $37 \%(3 \mathrm{~mL})$ were cooled to $0{ }^{\circ} \mathrm{C}$ in an ice bath. 5-Amino-2-methylbenzonitrile $\mathbf{1 0}(1.00 \mathrm{~g}, 7.5 \mathrm{mmol})$ was dissolved in this mixture and sodium nitrite $(0.573 \mathrm{~g}, 7.2 \mathrm{mmol})$ in water $(2.5 \mathrm{~mL})$ was added. The solution was allowed to stir at $0^{\circ} \mathrm{C}$ until all of the starting material dissolved (30 minutes). A solution of potassium iodide $(1.81 \mathrm{~g}, 11.2 \mathrm{mmol})$ in water $(2.5 \mathrm{~mL})$ was added and allowed to stir for an additional 30 minutes at $0^{\circ} \mathrm{C}$. Diethyl ether $(20 \mathrm{~mL})$ was added before stirring an additional $30 \mathrm{~min}$. The reaction mixture was loaded into a separatory funnel, and the organic layer was isolated. The aqueous layer was extracted with additional diethyl ether, then the organic extracts were washed with saturated aqueous sodium thiosulfate solution, saturated $\mathrm{NaHCO}_{3}$, water, and brine. The organic layer was dried over $\mathrm{MgSO}_{4}$, filtered, and concentrated, leaving an orange crystalline residue. Purification by chromatography (ethyl acetate/hexane 5/95) gave the product as a white solid $(0.780 \mathrm{~g}, 3.2 \mathrm{mmol})$. Yield: $43 \%$. Mp $68-70^{\circ} \mathrm{C}$. MS (ESI): $\mathrm{m} / z 244.1[\mathrm{M}+\mathrm{H}]^{+} .{ }^{1} \mathrm{H}$ NMR (300 MHz, $\mathrm{CDCl}_{3}$ ): $\delta 7.89$ (s, 1H, Ar), 7.78 (d, 1H, J 8.0 Hz, Ar), 7.03 (dd, 1H, J 8.0 Hz, $18 \mathrm{~Hz}, \mathrm{Ar}), 2.49$ (s, 3H). Anal. calcd for $\mathrm{C}_{8} \mathrm{H}_{7} \mathrm{IN}$. Calcd: C, 39.53; H, 2.49; N, 5.76. Found: C, $39.25 ; \mathrm{H}, 2.23 ; \mathrm{N}, 5.88$.

5-Hydroxy-2-methylbenzonitrile (11). ${ }^{35}$ 5-Amino-2-methylbenzonitrile $\mathbf{1 0}$ (1 g, $7.5 \mathrm{mmol}$ ) was dissolved in a solution of $\mathrm{H}_{2} \mathrm{SO}_{4}\left(4 \mathrm{~mL}\right.$, conc.) in $\mathrm{H}_{2} \mathrm{O}(12 \mathrm{~mL})$. Crushed ice $(10 \mathrm{~g})$ was added. 
Then, a solution of $\mathrm{NaNO}_{2}(0.650 \mathrm{~g}, 9.25 \mathrm{mmol})$ in $\mathrm{H}_{2} \mathrm{O}(4 \mathrm{~mL})$ was added dropwise below $5{ }^{\circ} \mathrm{C}$. Five minutes later, cold water $(5 \mathrm{~mL})$, urea $(0.070 \mathrm{~g}, 1.17 \mathrm{mmol})$ and ice $(5 \mathrm{~g})$ were added in sequence. The reaction mixture was added into a refluxed solution of $\mathrm{Na}_{2} \mathrm{SO}_{4}(5 \mathrm{~g}, 41 \mathrm{mmol})$ and conc. $\mathrm{H}_{2} \mathrm{SO}_{4}(10 \mathrm{~mL})$ in $\mathrm{H}_{2} \mathrm{O}(5 \mathrm{~mL})$. The resulting mixture was refluxed for $2 \mathrm{~h}$, then extracted with ethyl acetate for three times. Combined organic parts were dried over $\mathrm{Na}_{2} \mathrm{SO}_{4}$, filtered and concentrated affording the title product as a brown waxy solid $(0.550 \mathrm{~g}, 4.13 \mathrm{mmol})$. Yield: $55 \%$. MS (ESI): $m / z$ 134.1 [M+H] ${ }^{+} .{ }^{1} \mathrm{H}$ NMR $\left(300 \mathrm{MHz}, \mathrm{CDCl}_{3}\right): \delta 7.17(\mathrm{~d}, 1 \mathrm{H}, J 8.4 \mathrm{~Hz}), 7.05(\mathrm{~d}, 1 \mathrm{H}$, $J 2.6 \mathrm{~Hz}$ ), 6.96 (dd, 1H, $\left.J_{1} 8.4 \mathrm{~Hz}, J_{2} 2.6 \mathrm{~Hz}, \mathrm{Ar}\right), 4.99$ (brs, 1H, OH), 2.46 (s, 3H). Anal. calcd for $\mathrm{C}_{8} \mathrm{H}_{7} \mathrm{NO}$. Calcd: C, 72.16; H, 5.30; N, 10.52. Found: C, 72.05; H, 5.23; N, 10.28 .

5-Methoxy-2-methylbenzonitrile (9g) ${ }^{36} \mathrm{~A}$ solution of 5-hydroxy-2-methylbenzonitrile $11(0.500$ $\mathrm{g}, 3.75 \mathrm{mmol})$ and $\mathrm{K}_{2} \mathrm{CO}_{3}(1 \mathrm{~g}, 7.5 \mathrm{mmol}), \mathrm{CH}_{3} \mathrm{I}(1 \mathrm{~g}, 5.6 \mathrm{mmol}, 0.5 \mathrm{~mL})$, in dimethylformamide was stirred at $80{ }^{\circ} \mathrm{C}$ for two days. $\mathrm{CH}_{2} \mathrm{CI}_{2}(30 \mathrm{~mL})$ and brine $(30 \mathrm{~mL})$ were then added, and the organic phase separated. The aqueous phase was then extracted with $\mathrm{CH}_{2} \mathrm{Cl}_{2}(2 \times 30 \mathrm{~mL})$, and the combined organic phases were dried and concentrated under reduced pressure to give, after purification by column chromatography with silica gel (ethyl acetate/hexane 1/10) a brown liquid (0.500 g, $3.40 \mathrm{mmol})$. Yield: 91\%. MS (ESI): $\mathrm{m} / z$ 148.2 [M+H] $]^{+}$. Anal. calcd for $\mathrm{C}_{9} \mathrm{H}_{9} \mathrm{NO}$. Calcd: C, 73.45; H, 6.16; N, 9.52. Found: C, 73.25; H, 6.23; N, 9.58 .

5-(3,4-Dimethoxyphenyl)-2-methylbenzonitrile (9h). A solution of 5-iodo-2-methylbenzonitrile 9f $(0.400 \mathrm{~g}, 2.05 \mathrm{mmol}), 3$,4-dimethoxyphenylboronic acid $(2.55 \mathrm{mmol})$, and $\mathrm{Pd}\left(\mathrm{PPh}_{3}\right)_{4}(60 \mathrm{mg})$ in ethanol $(60 \mathrm{~mL})$ and $\mathrm{K}_{2} \mathrm{CO}_{3}(2 \mathrm{M}, 6 \mathrm{~mL})$ was refluxed for $3 \mathrm{~h}$. After the mixture had cooled, $\mathrm{CHCl}_{3}$ and aqueous saturated $\mathrm{NaHCO}_{3}$ were added. Insoluble materials were filtered. The aqueous layer was acidified with $1 \mathrm{M} \mathrm{HCl}$ and extracted with ethyl acetate. The organic layer was dried over $\mathrm{Na}_{2} \mathrm{SO}_{4}$ and concentrated in vacuo. Purification by chromatography (ethyl acetate/hexane 1/9) gave the product as white solid $(0.450 \mathrm{mg}, 1.77 \mathrm{mmol})$. Yield: $87 \%$. MS (ESI): $\mathrm{m} / z 254.1$ $[\mathrm{M}+\mathrm{H}]^{+}$. Mp 127-128 ${ }^{\circ} \mathrm{C}$ (ethyl acetate/hexane). ${ }^{1} \mathrm{H}$ NMR (300 MHz, $\left.\mathrm{CDCl}_{3}\right): \delta 7.61(\mathrm{~d}, 1 \mathrm{H}, J 1.6$ $\mathrm{Hz}, \mathrm{Ar}), 7.48$ (dd, 1H, $J_{1} 8.4 \mathrm{~Hz}, J_{2}$ 1.6, Hz, Ar), 7.35-7.31 (m, 2H, Ar), 6.65 (d, 2H, J 8.4 Hz, Ar), $3.80(\mathrm{~s}, 6 \mathrm{H}), 2.57(\mathrm{~s}, 3 \mathrm{H}) \cdot{ }^{13} \mathrm{C} \mathrm{NMR}\left(75 \mathrm{MHz}, \mathrm{CDCl}_{3}\right): \delta 157.3,139.9,135.4,134.9,132.3,129.5$, 129.3, 116.8, 112.2, 103.9, 55.8, 20.2. Anal. calcd for $\mathrm{C}_{16} \mathrm{H}_{15} \mathrm{NO}_{2}$. Calcd: C, 75.87; H, 5.97; N, 5.53. Found: C, 75.75; H, 6.13; N, 5.68 .

\section{General procedure for dibromination ${ }^{5}$}

A solution of substituted benzonitriles or substituted toluenes $(1 \mathrm{mmol})$ in CCl4 $(15 \mathrm{~mL})$ was treated with N-bromosuccinimide $(2.5 \mathrm{mmol})$ and benzoyl peroxide $(0.1 \mathrm{mmol})$. The solution was refluxed for $24 \mathrm{~h}$, cooled to r.t. and filtered to remove succinimide. The filtrate was concentrated and purified by column chromatography.

2-(Dibromomethyl)benzonitrile (7a). ${ }^{5,7}$ White solid $(0.241 \mathrm{~g}, 0.87 \mathrm{mmol})$. Yield: $87 \%$. Mp 64 $65{ }^{\circ} \mathrm{C}$ (ethyl acetate/hexane). MS (EI): $m / z(\%) 277(<1), 275(<1), 273(<1), 196(97), 194$ (100). 2-(Dibromomethyl)-5-nitrobenzonitrile (7b). ${ }^{37}$ Purified by column chromatography on silica gel (ethyl acetate/hexane 5/95) to give a pale oil ( $0.140 \mathrm{~g}, 0.44 \mathrm{mmol}$ ). Yield: $44 \%$. MS (EI): $\mathrm{m} / \mathrm{z} 241$ (97\%), 239 (100\%). $\left.{ }^{13} \mathrm{C} \mathrm{NMR} \mathrm{(60} \mathrm{MHz,} \mathrm{CDCl}_{3}\right)$ : $\delta 149.6,147.6,131.5,128.3,127.4,113.8,109.9$, 
33.5. Anal. calcd for $\mathrm{C}_{8} \mathrm{H}_{7} \mathrm{Br}_{2} \mathrm{~N}_{2} \mathrm{O}_{2}$. Calcd: C, 30.03; H, 1.26; N, 8.76. Found: C, 30.15; H, 1.33; N, 8.58 .

5-Chloro-2-(dibromomethyl)benzonitrile (7c). ${ }^{7}$ Purified by column chromatography on silica gel (ethyl acetate/hexane 2/98) to give a white solid (0.270 g, $0.88 \mathrm{mmol})$. Yield: $88 \%$. Mp. 74-75 ${ }^{\circ} \mathrm{C}$ (ethyl acetate/hexane). MS (EI): $m / z(\%) 311(<1), 309(<1), 307(<1), 230(100), 228$ (77). ${ }^{13} \mathrm{C} \mathrm{NMR}\left(100 \mathrm{MHz}, \mathrm{CDCl}_{3}\right): \delta 142.8,136.2,134.2,131.7,131.3,114.7,109.8,34.5$.

5-Bromo-2-(dibromomethyl)benzonitrile (7e). Purified by column chromatography on silica gel (ethyl acetate/hexane $2 / 98)$ to give a waxy solid (0.300 g, $0.85 \mathrm{mmol})$. Yield: $85 \%$. MS (EI): $\mathrm{m} / \mathrm{z}$ (\%) $357(<1), 355(<1), 353(<1), 351(<1), 276(49), 274$ (100), 272 (50\%). ${ }^{1} \mathrm{H}$ NMR $(250 \mathrm{MHz}$, $\left.\mathrm{CDCl}_{3}\right): \delta 7.89-7.72(\mathrm{~m}, 3 \mathrm{H}, \mathrm{Ar}), 6.92(\mathrm{~s}, 1 \mathrm{H}) .{ }^{13} \mathrm{C} \mathrm{NMR}\left(100 \mathrm{MHz}, \mathrm{CDCl}_{3}\right): \delta 142.8,136.2,134.2$, 131.7, 131.3, 114.7, 109.8, 34.5. Anal. calcd for $\mathrm{C}_{8} \mathrm{H}_{4} \mathrm{Br}_{3} \mathrm{~N}$. Calcd: C, 27.16; H, 1.14; N, 3.96. Found: C, 27.25; H, 1.53; N, 3.88 .

2-(Dibromomethyl)-5-iodobenzonitrile (7f). Purified by column chromatography on silica gel (ethyl acetate/hexane 2/98) to give a slightly yellow waxy solid $(0.200 \mathrm{~g}, 0.5 \mathrm{mmol})$. Yield: $50 \%$. MS (EI): $m / z(\%): 403(<1), 401(<1), 399(<1), 322$ (97\%), $320(100 \%),{ }^{1} \mathrm{H}$ NMR $(250 \mathrm{MHz}$, $\left.\mathrm{CDCl}_{3}\right): \delta 8.01(\mathrm{~d}, 1 \mathrm{H}, J 8.5 \mathrm{~Hz}, \mathrm{Ar}), 7.92(\mathrm{~s}, 1 \mathrm{H}, \mathrm{Ar}), 7.74(\mathrm{~d}, 1 \mathrm{H}, J 8.5 \mathrm{~Hz}, \mathrm{Ar}), 6.90(\mathrm{~s}, 1 \mathrm{H}) .{ }^{13} \mathrm{C}$ NMR (60 MHz, $\mathrm{CDCl}_{3}$ ): $\delta 144.0,143.2,140.6,131.4,114.6,110.2,95.2$, 35.1. Anal. calcd for $\mathrm{C}_{8} \mathrm{H}_{4} \mathrm{Br}_{2} \mathrm{IN}$. Calcd: C, 23.97; H, 1.01; N, 3.49. Found: C, 23.75; H, 1.33; N, 3.58.

2-(Dibromomethyl)-5-methoxybenzonitrile (7g). Purified by column chromatography on silica gel (ethyl acetate/hexane 2/98) to give a waxy solid (0.287 g, $0.95 \mathrm{mmol})$. Yield: $95 \%$. MS (EI): $m / z(\%) 307(<1), 305(<1), 303(<1), 226$ (97), 224 (100), ${ }^{1} \mathrm{H}$ NMR (250 MHz, $\left.\mathrm{CDCl}_{3}\right): \delta 7.91(\mathrm{~d}$, $1 \mathrm{H}, J 8.7 \mathrm{~Hz}, \mathrm{Ar}), 7.20-7.18(\mathrm{~m}, 1 \mathrm{H}, \mathrm{Ar}), 7.02$ (s, 1H, Ar), $6.95(\mathrm{~s}, 1 \mathrm{H}) .{ }^{13} \mathrm{C}$ NMR $(60 \mathrm{MHz}$, $\left.\mathrm{CDCl}_{3}\right): \delta 160.1,136.5,134.3,131.7,130.0,120.5,116.6,109.8,55.9,35.6$. Anal. calcd for $\mathrm{C}_{9} \mathrm{H}_{7} \mathrm{Br}_{2} \mathrm{NO}$. Calcd: C, 35.45; H, 2.31; N, 5.25. Found: C, 35.75; H, 2.37; N, 5.48.

2-(Dibromomethyl)-5-(3,4-dimethoxyphenyl)benzonitrile (7h). Purified by column chromatography on silica gel (ethyl acetate/hexane $2 / 98)$ to give a pale oil $(0.293 \mathrm{~g}, 0.72 \mathrm{mmol})$. Yield: 72\%. MS (EI): $m / z(\%) 413(<1), 411(<1), 409(<1), 332$ (97\%), $330(100 \%),{ }^{1} \mathrm{H} \mathrm{NMR}(300 \mathrm{MHz}$, $\mathrm{CDCl}_{3}$ ): $\delta 8.04(\mathrm{~d}, 2 \mathrm{H}, J 2.2 \mathrm{~Hz}, \mathrm{Ar}), 7.75-7.53(\mathrm{~m}, 3 \mathrm{H}, \mathrm{Ar}), 7.04(\mathrm{~s}, 1 \mathrm{H}), 6.70(\mathrm{~d}, 1 \mathrm{H}, J 8.9 \mathrm{~Hz})$, 3.76 (s, 3H), 3.42 (s, 3H). $\left.{ }^{13} \mathrm{C} \mathrm{NMR} \mathrm{(75} \mathrm{MHz,} \mathrm{CDCl}_{3}\right): \delta 157.3,139.9,135.4,134.9,132.3,129.5$, 129.3, 116.8, 112.2, 108.4, 60.7, 55.9, 35.6. Anal. calcd for $\mathrm{C}_{16} \mathrm{H}_{13} \mathrm{Br}_{2} \mathrm{NO}_{2}$. Calcd: C, 46.75; H, 3.19 ; N, 3.41. Found: C, 46.45; H, 3.33; N, 3.68.

2-(Dibromomethyl)-4-nitrobenzonitrile (7i). Purified by column chromatography on silica gel ((hexane/ethyl acetate $95 / 5)$ to give a slightly yellow solid $(0.160 \mathrm{~g}, 0.5 \mathrm{mmol})$. Yield: $50 \%$. Mp 83-84 ${ }^{\circ} \mathrm{C}$ (ethyl acetate/hexane). MS (EI): $m / z$ (\%) 241 (97), 239 (100). ${ }^{1} \mathrm{H}$ NMR (250 MHz, $\mathrm{CDCl}_{3}$ ): $\delta 8.84$ (s, 1H, Ar), 8.27 (d, 1H, J 8.4 Hz, Ar), 7.87 (d, $\left.1 \mathrm{H}, J 8.4 \mathrm{~Hz}, \mathrm{Ar}\right), 7.01(\mathrm{~s}, 1 \mathrm{H}) .{ }^{13} \mathrm{C}$ NMR (75 MHz, $\mathrm{CDCl}_{3}$ ): $\delta 150.5,146.3,133.9,124.9,124.6,114.2,113.9,33.6$. Anal. calcd for $\mathrm{C}_{8} \mathrm{H}_{7} \mathrm{Br}_{2} \mathrm{~N}_{2} \mathrm{O}_{2}$. Calcd: C, 30.03; H, 1.26; N, 8.76. Found: C, 30.17; H, 1.36; N, 8.48.

4-cyano-(dibromomethyl)benzonitrile (13b). ${ }^{38}$ Purified by column chromatography (hexane/ethyl acetate $95 / 5)$ to give a white solid (0.240 g, $0.89 \mathrm{mmol})$. Yield: $89 \%$. \%. Mp 81$82^{\circ} \mathrm{C}$ (ethyl acetate/hexane). 
1-(Dibromomethyl)-4-methoxybenzene (13c). ${ }^{39}$ Purified by column chromatography (hexane/ethyl acetate $95 / 5)$ to give a brown oil ( $0.240 \mathrm{~g}, 0.88 \mathrm{mmol})$. Yield: $88 \%$. MS (EI): $\mathrm{m} / \mathrm{z}$ $282(<1), 280(<1), 278(<1), 201$ (97), 199 (100). Anal. calcd for $\mathrm{C}_{8} \mathrm{H}_{5} \mathrm{Br}_{2} \mathrm{NO}$. Calcd: C, 34.32; H, 2.88. Found: C, 32.35; H, 2.67.

1-(Dibromomethyl)-4-nitrobenzene (13d). ${ }^{39}$ Purified by column chromatography (hexane/ethyl acetate 90/10) to give a white solid (0.196 g, $0.67 \mathrm{mmol})$. Yield: 67\%. Mp 76-77 C.

\section{General procedure for the hydrolysis of benzal bromides 7 or 13 to aldehydes}

A solution of benzal bromides 7 or $\mathbf{1 3}(0.6 \mathrm{mmol})$ in a mixture of dioxane/water $(5 \mathrm{~mL}, 1 / 1)$ was heated at $100{ }^{\circ} \mathrm{C}$ for the reaction times reported in the tables 1 and 2 . The reaction mixture was poured into water $(20 \mathrm{ml})$, and the resulting mixture was extracted with ethyl acetate $(40 \mathrm{ml} \times 3)$. The extract was washed with water twice, dried over anhydrous sodium sulfate, and concentrated under reduced pressure to give the aldehydes.

2-Formylbenzonitrile (commercially available, 1a). ${ }^{5,7}$ Purified by column chromatography on silica gel (ethyl acetate/hexane $4 / 6)$ to give a white solid $(0.070 \mathrm{~g}, 0.53 \mathrm{mmol})$. Yield: $94 \%$. Mp 104-106 ${ }^{\circ} \mathrm{C}$ (ethyl acetate/hexane). MS (ESI): $m / z 132.1[\mathrm{M}+\mathrm{H}]^{+}$.

2-Formyl-5-nitrobenzonitrile (1b). Purified by column chromatography on silica gel (ethyl acetate/hexane 5/95) to give a waxy solid $(0.040 \mathrm{~g})$. Yield: $38 \%$. MS (ESI): $\mathrm{m} / z 177.0[\mathrm{M}+\mathrm{H}]^{+} .{ }^{1} \mathrm{H}$ NMR $\left(250 \mathrm{MHz}, \mathrm{CDCl}_{3}\right) \delta 10.41(\mathrm{~s}, 1 \mathrm{H}), 8.68(\mathrm{~s}, 1 \mathrm{H}, \mathrm{Ar}), 8.60(\mathrm{~d}, J 8.7 \mathrm{~Hz}, 1 \mathrm{H}, \mathrm{Ar}), 8.26(\mathrm{~d}, J$ $8.5 \mathrm{~Hz}, 1 \mathrm{H}, \mathrm{Ar})$. Anal. calcd for $\mathrm{C}_{8} \mathrm{H}_{4} \mathrm{~N}_{2} \mathrm{O}_{3}$. Calcd: C, 54.55; H, 2.29; N, 15.91. Found: C, 54.67; $\mathrm{H}, 2.37$; N,15.79.

5-Chloro-2-formylbenzonitrile (1c). ${ }^{6}$ Purified by column chromatography on silica gel (ethyl acetate/hexane 3/7) to give a white solid $(0.074 \mathrm{~g}, 0.45 \mathrm{mmol})$. Yield: $75 \%$. Mp $110-112^{\circ} \mathrm{C}$ (ethyl acetate/hexane). MS (ESI): $m / z$ 165.1 $[\mathrm{M}+\mathrm{H}]]^{+} .{ }^{13} \mathrm{C}$ NMR (100 MHz, DMSO-d 6 ) $\delta$ 189.6, 167.7, $145.8,134.4,134.3,132.4,126.0,122.6$.

5-Fluoro-2-formylbenzonitrile (1d). ${ }^{5}$ Purified by column chromatography on silica gel (ethyl acetate/hexane 5/95) to give a white solid $(0.068 \mathrm{~g}, 0.45 \mathrm{mmol})$. Yield: $76 \%$. Mp 120-121 ${ }^{\circ} \mathrm{C}$ (ethyl acetate/hexane). MS (ESI): $m / z 150.0[\mathrm{M}+\mathrm{H}]^{+}$.

5-Bromo-2-formylbenzonitrile (1e). ${ }^{33}$ Purified by column chromatography on silica gel (ethyl acetate/hexane $3 / 7)$ to give a white solid $\left(0.091 \mathrm{~g}, 0.44 \mathrm{mmol}\right.$ ). Yield: $73 \%$. Mp 131-132 ${ }^{\circ} \mathrm{C}$ (ethyl acetate/hexane). MS (ESI): $m / z 208.9[\mathrm{M}+\mathrm{H}]^{+}$.

2-Formyl-5-iodobenzonitrile (1f). Purified by column chromatography on silica gel (ethyl acetate/hexane $2 / 98)$ to give a slightly yellow solid (0.111 g, $0.44 \mathrm{mmol})$. Yield: $73 \%$. MS (ESI): $m / z 257.9[\mathrm{M}+\mathrm{H}]^{+}$. Mp. $121-122{ }^{\circ} \mathrm{C}$ (ethyl acetate/hexane). ${ }^{1} \mathrm{H}$ NMR $\left(300 \mathrm{MHz}, \mathrm{CDCl}_{3}\right): \delta 10.26$ (s, 1H), 8.17-8.07 (m, 2H, Ar), $8.73(\mathrm{~d}, J 8.1 \mathrm{~Hz}, 1 \mathrm{H}, \mathrm{Ar}) .{ }^{13} \mathrm{C} \mathrm{NMR}\left(75 \mathrm{MHz}, \mathrm{CDCl}_{3}\right): \delta$ 187.7, 142.5, 142.3, 135.8, 130.1, 114.9, 114.3, 101.4. Anal. calcd for $\mathrm{C}_{8} \mathrm{H}_{4} \mathrm{Br}_{2} \mathrm{INO}$. Calcd: C, 37.38; H, 1.57; N, 5.45. Found: C, 37.35; H, 1.33; N, 5.58.

2-Formyl-5-methoxybenzonitrile (1g). Purified by column chromatography on silica gel (ethyl acetate/hexane $2 / 98$ ) to give a white solid $(0.073 \mathrm{~g}, 0.45 \mathrm{mmol})$. Yield: $76 \%$. MS (ESI): $\mathrm{m} / \mathrm{z} 162.0$ $[\mathrm{M}+\mathrm{H}]^{+} . \mathrm{Mp} .77-78{ }^{\circ} \mathrm{C}$ (ethyl acetate/hexane). ${ }^{1} \mathrm{H} \mathrm{NMR}\left(250 \mathrm{MHz}, \mathrm{CDCl}_{3}\right): \delta 10.21(\mathrm{~s}, 1 \mathrm{H}), 7.97$ 
(d, J 8.5 Hz, 1H, Ar), 7.25-7.21 (m, 2H, Ar), 3.93 (s, 3H). $\left.{ }^{13} \mathrm{C} \mathrm{NMR} \mathrm{(60} \mathrm{MHz,} \mathrm{CDCl}_{3}\right): \delta 187.5$, 164.0, 131.9, 130.3, 119.2, 119.0, 116.0, 115.8, 56.4. Anal. calcd for $\mathrm{C}_{9} \mathrm{H}_{7} \mathrm{NO}_{2}$. Calcd: $\mathrm{C}, 67.07$; H, 4.38; N, 8.69. Found: C, 67.05; H, 4.47; N, 8.48.

5-(3,4-Dimethoxyphenyl) 2-formylbenzonitrile (1h). Purified by column chromatography on silica gel (ethyl acetate/hexane 2/98) to give a white solid (0.113 g, $0.42 \mathrm{mmol})$. Yield: 71\%. M.p. 159-160 ${ }^{\circ} \mathrm{C}$ (ethyl acetate/hexane). MS (ESI): $m / z 268.1[\mathrm{M}+\mathrm{H}]^{+} .{ }^{1} \mathrm{H} \mathrm{NMR}\left(300 \mathrm{MHz}, \mathrm{CDCl}_{3}\right): \delta$ 10.37 (s, 1H), 8.09-8.04 (m, 1H, Ar), 7.90-7.81 (m, 2H, Ar), 7.59-7.53 (m, 1H, Ar), 6.73-6.67 (m, 2H, Ar), $3.76(\mathrm{~s}, 3 \mathrm{H}), 3.42(\mathrm{~s}, 3 \mathrm{H}) .{ }^{13} \mathrm{C} \mathrm{NMR}\left(75 \mathrm{MHz}, \mathrm{CDCl}_{3}\right): \delta 188.4,156.5,140.3,136.3$, 135.6, 133.8, 130.9, 128.9, 126.9, 113.2, 108.5, 60.7, 56.0. Anal. calcd for $\mathrm{C}_{16} \mathrm{H}_{13} \mathrm{NO}_{3}$. Calcd: $\mathrm{C}$, 71.90; H, 4.90; N, 5.24. Found: C, 71.85; H, 5.13; N, 5.48 .

2-Formyl 4-nitrobenzonitrile (1i). Purified by column chromatography on silica gel (ethyl acetate/hexane 5/95) to give a to give a yellow waxy solid (0.015 g). Yield: $15 \%$. MS (ESI): $\mathrm{m} / \mathrm{z}$ $177.0[\mathrm{M}+\mathrm{H}]^{+} .{ }^{1} \mathrm{H}$ NMR $\left(250 \mathrm{MHz}, \mathrm{CDCl}_{3}\right): \delta 10.41(\mathrm{~s}, 1 \mathrm{H}), 8.84(\mathrm{~s}, 1 \mathrm{H}, \mathrm{Ar}), 8.57(\mathrm{~d}, J 8.5 \mathrm{~Hz}$, $1 \mathrm{H}), 8.07$ (dd, $J_{1} 8.5 \mathrm{~Hz}, J_{2} 2.0 \mathrm{~Hz}, 1 \mathrm{H}, \mathrm{Ar}$ ). Anal. calcd for $\mathrm{C}_{8} \mathrm{H}_{4} \mathrm{~N}_{2} \mathrm{O}_{3}$. Calcd: C, 54.55; H, 2.29; N, 15.91. Found: C, 54.67; H, 2.37; N,15.79.

4-Cyanobenzaldehyde (commercially available, 14b). ${ }^{40}$ White solid $(0.074 \mathrm{~g}, 0.57 \mathrm{mmol})$. Yield: 95\%. Mp 98-99 ${ }^{\circ} \mathrm{C}$.

4-Methoxybenzaldehyde (commercially available, 14c). ${ }^{40}$ Colorless oil $(0.078 \mathrm{~g}, 0.57 \mathrm{mmol})$. Yield: 96\%. MS (ESI): $m / z$ 137.1 [M+H] $]^{+}$. Anal. calcd for $\mathrm{C}_{8} \mathrm{H}_{8} \mathrm{NO}_{2}$. Calcd: C, 70.57; H, 5.92 . Found: C, 70.85; H, 5.83 .

4-nitrobenzaldehyde (commercially available, $14 d) .{ }^{40}$ Purified by column chromatography on silica gel (ethyl acetate/hexane 1/9). Yellow crystals (0.071 g, $0.47 \mathrm{mmol})$. Yield: 78\%. Mp. 103$105^{\circ} \mathrm{C}$.

\section{Acknowledgements}

We thank the University of Salerno for financial support

\section{References}

1. Perillo, M.; Di Mola, A.; Filosa, R.; Palombi, L.; Massa, A. RSC Adv. 2014, 4, 4239. http://dx.doi.org/10.1039/C3RA46268D

2. More, V.; Rohlmann, R.; García Mancheño, O.; Petronzi, C.; Palombi, L.; De Rosa, A.; Di Mola, A. Massa, A. RSC Adv. 2012, 2, 3592 http://dx.doi.org/10.1039/C3RA46268D 10.1039/C2RA20231J.

3. S. Tiso, L. Palombi, C. Vignes, A. Di Mola, A. Massa, A. RSC $A d v$. 2013, 3, 19380. http://dx.doi.org/10.1039/C3RA43074J 
4. Petronzi, C.; Collarile, S.; Croce, G.; Filosa, R.; De Caprariis, P.; Peduto, A.; Palombi, L.; Intintoli, V.; Di Mola, A.; Massa A. Eur. J. Org. Chem. 2012, 5357. http://dx.doi.org/10.1002/ejoc.201200678

5. Sun, C.; Xu, B. J. Org. Chem. 2008, 73, 7361. http://dx.doi.org/10.1021/j0801219j

6. Kobayashi, K.; Matsumoto, K.; Nakamura, D.; Fukamachi, S.; Konishi, H. Helv. Chim. Acta 2010, 93, 1048. http://dx.doi.org/10.1002/hlca.201000035

7. Lippman, W.; Demerson, C.A.; Humber, L. G.; Ferland, J. M. USP 4244966, 13 January 1981.

8. Sato, R.; Senzaki, T.; Goto. T.; Saito, G. Chem. Lett. 1984, 61, 1599. http://dx.doi.org/10.1246/cl.1984.1599

9. Sato, R.; Ohmori, M.; Kaitani, F.; Kurosawa, A.; Senzaki, T.; Goto. T.; Saito, G. Bull. Chem. Soc. Jpn. 1986, 59, 2950. http://dx.doi.org/10.1246/bcsj.59.2950.

10. Angelin, M.; Rahm, M.; Fischer, A.; Brinck, T.; Ramstroem, O. J. Org. Chem. 2010, 75, 5882. http://dx.doi.org/10.1021/jo100868z.

11. Liu, M.; Li, J.; Zhang, Q.; Shi, D. Heterocycles 2015, 91, 1465. http://dx.doi.org/10.3987/COM-15-13247.

12. Li, T.; Zhou, S.; Wang, J.; Acena, J. L.; Soloshonok, V. A.; Liu, H. Chem. Commun., 2015, $51,1624$. http://dx.doi.org/10.1039/C4CC05659K.

13. Shen, S.; Xu, X.; Lei, M.; Hu, L. Synthesis 2012, 44, 3543. http://dx.doi.org/10.1055/s-0032-1317472.

14. Sato, R.; Ohmori, M.; Kaitani, F.; Kurosawa, A.; Senzaki, T.; Goto. T.; Saito, G. Bull. Chem. Soc. Jpn. 1988, 61, 2481. http://dx.doi.org/10.1246/bcsj.61.2481

15. Shen, S.; Khang, P. V.; Chen, Y.; Lei, M.; Hu, L. Arkivoc 2013, (iii), 413.

16. Astles, P. C.; Brown, T. J.; Halley, F., Handscombe, C. M.; Harris, N. V.; McCarthy, C.; McLay, I. M.; Lockey, P.; Majid, T.; Porter, B.; Roach, A. G.; Smith, C.; Walsh, R. J. Med. Chem. 1998, 41, 2745. http://dx.doi.org/10.1021/jm970847e.

17. Katritzky, A. R. Cook, M. J.; Brown, S. B.; Cruz, R.; Millet G. H.; Anani A. J. Chem. Soc., Perkin Trans. 1, 1979, 249. http://dx.doi.org/10.1039/P19790002493

18. Leach, C. A.; Liddle, J.; Peace, S.; Philp, J.; Smith, E. D.; Terrell, L. R.; Zhang, J. PCT Int. Appl. 2006, WO 2006067462A1 (Glaxo UK).

19. Noeel, T.; Vandyck, K.; Van der Eycken, J. PCT Int. Appl. 2010, WO 2010115903A1.

20. Semmelhack, M. F.; Ho, S.; Cohen, D.; Steigerwad, M.; Lee, M. C.; Lee, G.; Gilbert, A. M.; Wufll, W. D.; Ball, R. G. J. Am. Chem. Soc. 1994, 116, 7108. http://dx.doi.org/10.1021/ja00095a014. 
21. Shamblee, D. A.; Gillespie, S. G., Jr. J. Med. Chem. 1979, 22, 86. http://dx.doi.org/10.1021/jm00187a019.

22. Blicke, F. F.; Patelski, R. A. J. Am. Chem. Soc. 1936, 58, 559. http://dx.doi.org/10.1021/ja01295a004.

23. Khatuya, H. Tetrahedron Lett. 2001, 42, 2643.

24. Angelini, G.; Giancaspro, C.; Illuminati, G.; Sleiter, G. J. Org. Chem. 1980, 45, 1786. http://dx.doi.org/10.1021/jo01298a009.

25. Chung, S. J.; Kim, D. H. Tetrahedron 1995, 51, 12549. http://dx.doi.org/10. 1016/00404020(95)00809-M.

26. Goodman, M. S.; Hamilton, A. D.; Weiss, J. J. Am. Chem. Soc. 1995, 117, 8447. http://dx.doi.org/10.1021/ja00137a021.

27. Bankston, D. Synthesis 2004, 2, 283. http://dx.doi.org/10.1055/s-2003-44390

28. Wang, Y.; Zhao, H.; Hu, Z.; Kimura, M.; Zhang, Z.; Peng, L.; Hiratsuka K. Synthesis 2011, 2 , 287. http://dx.doi.org/10.1055/s-0030-1258362

29. Salomaa P. In The Chemistry of the Carbonyl Group, Vol. 1; Patai, S., Ed.; Wiley: New York, 1966; p177.

30. Li, W.; Li, J.; De Vincentis, D.; Mansour T. S. Tetrahedron Lett. 2004, 45, 1071. http://dx.doi.org/10.1016/j.tetlet.2003.11.072

31. Remy, C.C.; King, S.W.; Cochran, D. J. Org. Chem., 1985, 50, 4120. http://dx.doi.org/10.1021/jo00196a003.

32. King, S. W.US 4590276 A May 20, 1986.

33. Chang, Y.; Chow, T. J. J. Mater. Chem., 2011, 21, 9523. http://dx.doi.org/10.1039/C1JM10107B.

34. Bryan D.; Kretz, C. A.; Xu, Y.; Holmes, A.; Sun, H.; Ginsburg, D.; Larsen, S.D. Bioorg. Med. Chem. Lett. 2014, 24, 1538. http://dx.doi.org/10.1016/j.bmcl.2014.01.079

35. Wan, Z.; Zhang, X.; Tong, Z.; Long, K.; Dowdell, S.E.; Manas, E. S.; Goodman, K.B. PCT Int. Appl. (2012), WO 2012037782 A1 Mar 29, 2012

36. Yestrepsky, B. D.; Xu, Y.; Breen, M.E.; Li, X.; Rajeswaran, W. G.; Ryu, J. G.; Sorenson, R.J.; Tsume, Y.; Wilson, M. W.; Zhang, W. Bioorg. Med. Chem. 2013, 21, 1880. http://dx.doi.org/10.1016/j.bmc.2013.01.046

37. Makosza, M.; Owczarczyk, Z. J. Org. Chem 1989, 54, 5094. http://dx.doi.org/10.1021/jo00282a025

38. Xi, H.; Gibb, C. L. D.; Gibb, B. C. J. Org. Chem 1999, 64, 9286. http://dx.doi.org/10.1021/j09909913

39. Pingali, S. R. K.; Upadhyay, S.K.; Jursic, B. S. Green Chemistry 2011, 13, 928. http://dx.doi.org/10.1039/C0GC00794C

40. Tabata, M.; Moriyama,K.; Togo, H. Eur. J. Org. Chem. 2014, 3402. http://dx.doi.org/10.1002/ejoc.201402015 